\title{
Peningkatan kompetensi guru dalam menyusun rencana pelaksanaan pembelajaran (RPP) daring melalui metode in house training (IHT)
}

\author{
Harnieti Harnieti*) \\ Unit Pelaksana Teknis Daerah, Sekolah Menengah Pertama Negeri 1 Kecamatan Luak, Indonesia
}

\begin{tabular}{l}
\hline Article Info \\
\hline Article history: \\
Received Dec $26^{\text {th }}, 2021$ \\
Revised Jan $14^{\text {th }}, 2021$ \\
Accepted Feb $20^{\text {th }}, 2021$ \\
\hline
\end{tabular}

\section{Keyword:}

Competence

Online learning

Implementation plan

In house training

\begin{abstract}
This article aims to analyze the improvement of teacher competence in compiling an Online Learning Implementation Plan (RPP) by applying the In House Training (IHT) method to teachers. The research subjects were teachers who had low competence in compiling online lesson plans with five men and 15 women. This research is a School Action Research which was carried out in two cycles, and each cycle was carried out for two meetings. The data collection technique was carried out by direct observation and accompanied by the vice principal as an observer by using an observation sheet. Then the results of the observations will be analyzed by looking at the increase in each cycle. In the initial conditions, the competence of teachers in preparing online lesson plans was $35.48 \%$. After taking action through In House Training, the competence of teachers in preparing online lesson plans in cycle 1 is $70.42 \%$. An increase in cycle 2 to $87.92 \%$ (very good). The results of this study indicate that there is an increase in teacher competence in preparing online lesson plans from cycle 1 to cycle two with an average increase of $17.5 \%$. Based on the results of this study, it can be concluded that the application of the In House Training method can improve the competence of teachers in preparing online lesson plans.
\end{abstract}

(C) 2021 The Authors. Published by IICET.

This is an open access article under the CC BY-NC-SA license

(https://creativecommons.org/licenses/by-nc-sa/4.0

\section{Corresponding Author:}

Harnieti,

Unit Pelaksana Teknis Daerah, Sekolah Menengah Pertama Negeri 1 Kecamatan Luak, Indonesia

Email: harnieti06@gmail.com

\section{Pendahuluan}

Berdasarkan Permeneg PAN-RB Nomor 16 tahun 2009 BAB III pasal 6 dinyatakan bahwa tugas pokok guru adalah merencanakan pembelajaran, melaksanakan pembelajaran yang bermutu, menilai dan mengevaluasi hasil pembelajaran, serta melaksanakan pembelajara, perbaikan dan pengayaan (Anugrah, 2019; Muhardiansyah, 2019). Selain itu, sesuai Permendikbud Nomor 22 Tahun 2016 tentang Standar Proses menyatakan bahwa standar proses untuk satuan pendidikan dasar dan menengah mencakup perencanaan proses pembelajaran, pelaksanaan proses pembelajaran, penilaian hasil pembelajaran, dan pengawasan proses pembelajaran (Pendidikan \& Indonesia, 2016). Standar proses ini mengandung makna bahwa proses pembelajaran perlu direncanakan, dilaksanakan, dinilai, dan diawasi agar terlaksana secara efektif dan efisien. Guru merupakan komponen yang memegang peranan utama dan sebagai fasilitator pembelajaran. Menurut (Sanjaya, 2015) ada 5 tugas pokok yang harus dikerjakan oleh setiap guru, tugas pokok tersebut antara lain: (1) Menjabarkan isi kurikulum, yaitu tugas guru dalam menyusun perencanaan pembelajaran, seperti 
menyusun program tahunan, semesteran, mingguan sampai ke program harian (2) Melaksanakan pembelajaran, yakni tugas guru menyampaikan tujuan dan materi pembelajaran dengan memilih metode, penggunaan alat/media dalam pembelajaran (3) Melaksanakan evaluasi/penilaian (4) Melaksanakan tugas dengan rasa tanggung jawab (5) Melaksanakan disiplin dalam arti luas.

RPP adalah perencanaan pembelajaran yang disusun oleh seorang guru agar memberikan kemudahan dan dapat dijadikan acuan atau pedoman dalam melaksanakan pembelajaran (Widiyanto \& Wahyuni, 2020). Pelaksanaan pembelajaran harus betul-betul sesuai dengan perancanaan. Untuk itu perencanaan atau RPP yang disusun oleh guru harus mampu mengakomodasi setiap hal yang terkait seperti karakteristik peserta didik, mau pun situasi dan kondisi yang ada. Pada masa pandemic covid-19 saat ini, terjadi perubahan yang signifikan dalam pelaksanaan pembelajaran. Dalam rangka memutus mata rantai penyebaran virus ini pemerintah mengeluarkan kebijakan. Kebijakan pertama dengan keluarnya SE Mendikbud Nomor 4 Tahun 2020 dan Terakhir keluarnya SKB 4 Menteri tentang kebijakan pendidikan pada masa darurat covid-19 (Atsani, 2020; Mansyur, 2020).

Semenjak diberlakukannya kebijakan tersebut, maka mengubah pola pembelajaran, yaitu dari pola tatap muka (face to face) ke pembelajaran daring atau pembelajaran jarak jauh (PJJ). Walaupun pembelajaran dilaksanakan melalui pembelajaran jarak jauh, namun kualitas pendidikan kita harapkan tidak mengalami penurunan dari biasanya (Putrianingsih, Muchasan, \& Syarif, 2021). Maka dalam situasi keterbatasan ini, maka perlu melakukan berbagai trik. Bagaimana mengoptimalkan potensi dan kompetensi guru sehingga, pembelajaran tetap berjalan dengan baik. Sebab kunci sukses dalam pembelajaran terletak pada kompetensi guru. Kompetensi guru adalah kemampuan yang dimilki guru dalam menjalankan tugas-tugas pokoknya dalam mengajar dan mendidik di sekolah.Kompetensi yang dimiliki akan menunjukkan kualitasnya dalam mengajar. Kompetensi tersebut akan terwujud dalam bentuk penguasaan pengetahuan, dan professional dalam menjalankan fungsinya (Darmadi, 2016; Majid, 2008).

Kepala sekolah merupakan pemimpin pembelajar dan supervisor yang berkewajiban melaksanakan tugasnya untuk kemajuan pendidikan di sekolah yang dipimpinnya (Erdianti, 2014; Mahardhani, 2016). Seorang kepala sekolah dituntut memiliki pengelolaan yang baik dalam melaksanakan tugasnya. Kepala sekolah akan dapat mengetahui sampai di mana kemampuan pendidik dalam merencanakan dan memberikan pendidikan serta menstransfer ilmu dalam mewujudkan peserta didik yang cerdas, terampil, mandiri dan mempunyai karakter baik sesuai dengan norma agama dan adat istiadat yang berlaku. Salah satunya adalah dengan melaksanakan monitoring dan evaluasi terhadap perencanaan yang dibuat oleh guru (Zaedi \& Rizkia, 2019).

Berdasarkan Permendikbud Nomor 6 Tahun 2018, bahwa tugas pokok seorang kepala sekolah adalah manajerial, supervisi dan kewirausahaan. Berdasarkan ketentuan di atas kepala sekolah perlu melaksanakan fungsinya meningkatkan mutu penyelenggaraan pendidikan di sekolah (Nuridin, Maerani, Soleh, \& Anwar, 2019). Kepala sekolah sebagai seorang manajerial, berupaya meningkatkan mutu guru melalui bimbingan dengan melakukan Penelitian Tindakan Sekolah. Melaksanakan Penelitian Tindakan Sekolah (PTS) berarti kepala sekolah telah bertanggungjawab serta dan berperan aktif dalam mengembangkan ilmu pengetahuan dan keterampilan sendiri yang berkaitan dengan tugas pokok kepala sekolah (Pohan \& Siregar, 2018). Diantara tugas pokok tersebut yaitu memantau, menilai, membina, dan melaporkan, serta melaksanakan tindak lanjut hasil pengawasan terhadap guru dalam menyusun perangkat pembelajaran (Komariah, 2009).

Fenomena yang ada di UPTD SMPN 1 Kecamatan Luak adalah belum semua guru memiliki kompetensi menyusun RPP yang digunakan untuk pembelajaran daring atau jarak jauh (PJJ). Berdasarkan supervisi yang penulis lakukan, kebanyakan guru saat ini masih menggunakan RPP untuk pembelajaran tatap muka yang disusun berdasarkan Permendikbud Nomor 22 tahun 2016. Berdasarkan wawancara yang penulis lakukan dengan guru diakhir supervisi, alasan mereka adalah karena tidak paham tentang RPP daring yang dipakai saat pembelajaran jarak jauh sekarang ini. Salah satu bentuk kegiatan yang dapat diadakan untuk meningkatkan kompetensi guru adalah In House Training (IHT) (Jayadipura, 2018).

In House Training adalah pelatihan yang dilaksanakan secara internal oleh kelompok kerja guru, sekolah atau tempat lain yang ditetapkan sebagai penyelenggara pelatihan (Jamaluddin, 2020; Sudarwan, 2010). Pelatihan dilaksanakan untuk meningkatkan kompetensi guru dan kariernya secara internal yang dipandu oleh seorang trainer atau mereka yang telah memiliki kompetensi lebih baik dari yang lainnya, dengan jumlah peserta minimal 4 (empat) orang. Kelemahan kemampuan guru dalam menyusun RPP Daring ini, perlu segera diatasi. Untuk itu peneliti selaku kepala sekolah tertarik melakukan Penelitian Tindakan Sekolah (PTS) dengan tujuan untuk menganalisis peningkatan kompetensi guru dalam menyusun recana pelaksanaan pembelajaran (rpp) dalam jaringan (daring) melalui metode in house training (IHT). 


\section{Metode}

Penelitian Tindakan Sekolah (PTS) ini dilaksanakan di UPTD SMPN 1 Kecamatan Luak Semester 1 TP. 2020/2021, yaitu pada bulan bulan Juli sampai dengan September 2020. Subjek penelitian adalah guru yang berjumlah 20 orang, yaitu laki-laki berjumlah 5 orang dan perempuan sebanyak 15 orang dari sepuluh mata pelajaran. Metode yang digunakan adalah In House Training (IHT). Adapun teknik pengumpulan data dilakukan dengan observasi langsung dan didampingi oleh wakil kepala sekolah sebagai observer dengan menggunakan lembar observasi. Kemudian hasil pengamatan akan dianalisis dengan melihat peningkatannya dalam setiap siklus, dengan menggunakan instrument penilaian RPP, catatan lapangan, dan lembar observasi. Data selanjutnya dianalisis dengan mencari presentase.

\section{Hasil dan Pembahasan}

\section{Kondisi Awal}

Pada kondisi awal guru yang sudah memiliki kompetensi menyusun RPP daring baru 11 orang (35,48\%). Sementara 20 orang (64,52\%) lagi masih menggunakan RPP biasa/tatap muka dalam melaksanakan pembelajaran jarak jauh.

\section{Siklus 1}

1. Perencanaan Kegiatan

Perencanaan yang peneliti lakukan pada siklus 1 ini adalah dengan menyusun rencana kegiatan. Kegiatan yang penulis lakukan adalah menyiapkan dokumen yang dibutuhkan dalam pelaksanaan kegiatan nantinya, yaitu sebagai berikut:
a. Menentukan jadwal kegiatan In House Training
b. Menyusun panduan IHT
c. Melakukan sosialisasi kegiatan IHT
d. Mengkoordinir tempat dan sarana yang dibutuhkan saat IHT
e. Membuat instrumen penilaian RPP
f. Membuat format catatan lapangan
g. Menyiapkan contoh RPP daring

2. Pelaksanaan Tindakan

Pertemuan pertama siklus I dilaksanakan pada Sabtu tanggal 20 Juli 2020. Dalam pelaksanaan tindakan pada siklus I, peneliti menjelaskan tentang SE Mendikbud Nomor 14 tahun 2019 tentang penyederhanaan RPP yang harus dipedomani oleh guru dalam menyusun RPP. Selajutnya juga memaparkan tentang jenis aplikasi daring yang dapat digunakan dalam pembelajaran jarak jauh (PJJ). Dilanjutkan dengan membahas tentang penggunaan jenis aplikasi daring dalam RPP. Dalam kegiatan ini guru diberi kesempatan untuk bertanya tentang hal-hal yang belum dipahaminya. Selanjutnya guru dengan mata pelajaran sejenis diminta duduk berkelompok untuk menyusun RPP daring. Peneliti mengamati dan memberikan masukan terhadap RPP yang disusun guru.

Setelah guru paham maka mereka diminta untuk merevisi RPP sesuai dengan materi yang akan mereka sampaikan pada pertemuan berikutnya. Pertemuan kedua dilaksanakan pada Sabtu, tanggal 1 Agustus 2020. Guru dengan mata pelajaran sejenis kembali duduk berkelompok untuk melakukan finishing RPP daring masing-masing yang telah dibuatnya. Pada akhir kegiatan beberapa guru diminta untuk memprensentasikan hasil diskusinya, memaparkan RPP yang telah disusun dan ditanggapi oleh peserta lain. Penulis memberikan masukan untuk direvisi oleh guru. Kegiatan ini dilaksanakan setelah pembelajaran berakhir. Tujuanlah adalah agar guru dapat berkonsentrasi dan tidak mengganggu PBM di sekolah. Kegiatan ini juga memiliki tujuan agar guru memiliki perencanaan yang sesuai dengan kondisi saat ini.

Diakhir kegiatan siklus 1 peneliti kembali memonitor perangkat RPP daring guru yang dibuat . Ternyata hasilnya masih jauh dari harapan. Tetapi kelemahan-kelemahan ini akan peneliti jadikan sebagai catatan untuk perbaikan pada siklus berikutnya. Peneliti memberikan masukan agar guru dapat membedakan antara pembelajaran daring dan luring. Selain itu tak kalah pentingnya bagaimana guru dapat menemukan ide inovatif terhadap metode pembelajaran agar tidak monoton dan membosankan bagi peserta didik. Apalagi saat PJJ saekarang ini, diharapkan pembelajaran tetap bermakna dan menyenangkan bagi mereka. Upaya yang dilakukan adalah dengan memberikan contoh RPP daring kepada guru. 
3. Observasi

Dalam pelaksanaan kegiatan peneliti melakukan kegiatan In House Traning (IHT). Materi kegiatan pada siklus 1 ini adalah tentang RPP daring. Peneliti menyimpulkan bahwa terjadi perubahan RPP yang dibuat oleh guru setelah mengikuti kegiatan In House Training (IHT). Walau pun kualitasnya belum sesuai dengan harapan. Hal ini dijadikan acuan untuk merencanakan siklus berikutnya. Selesai satu siklus, maka peneliti meminta guru yang mengikuti kegiatan In Hosue Training (IHT) untuk mengumpulkan RPP Dalam Jaringan (daring) yang telah mereka buat. Selanjutnya bersama observer, peneliti memberikan penilaian terhadap RPP sesuai dengan instrumen yang telah ditetapkan. Selanjutnya peneliti menetapkan target bimbingan berikutnya, berdasarkan hasil penilaian.

Pada siklus 1 kompetensi guru dalam menyusun RPP daring rata-rata pertemuan 1 (pertama) 60,83\%, pada pertemuan ke-2 (kedua) meningkat menjadi $80 \%$. Total rata-ratanya adalah $70,42 \%$. Jadi dapat disimpulkan bahwa terdapat peningkatan yang positif terhadap kompetensi guru dalam menyusun RPP daring secara signifikan.

4. Refleksi

Berdasarkan hasil pengamatan/observasi yang dilakukan terhadap kompetensi guru dalam menyusun RPP daring dan catatan di lapangan peneliti dan kolaborator melalui In House Training, maka refleksi pada siklus I ditemukan hal-hal sebagai berikut:

a. Masih terdapat guru yang kurang serius dalam mengikuti kegiatan In House Training. Hal ini dapat dilihat dari kedisiplinan mereka dalam mengikuti kegiatan. Masih terdapat guru yang belum mampu menyusun RPP daring. Hal ini dapat dilihat pada kegiatan inti yang belum menggunakan aplikasi pembelajaran daring. Maka dalam hal ini kepala sekolah dan juga peneliti berusaha melakukan pendekatan untuk menggali kesulitan guru dalam menyusun RPP daring. Sehingga pada siklus 1 guru dapat menceritakan tentang apa saja yang menjadi kendala baginya dalam menyusun RPP daring. Selanjutnya peneliti memberikan masukan yang dapat membantu guru dengan memberikan masukan tentang RPP yang sedang dirancangnya. Hubungan yang akrab dan harmonis akan menciptakan dialog yang baik dengan guru. Sehingga guru termotivasi untuk melaksanakan kegiatannya dengan baik, yaitu menyusun RPP daring dan juga siap untuk mengikuti In House Training (IHT) berikutnya.

b. Setelah selesai siklus I, maka kepala sekolah yang juga peneliti diharapkan dapat memberikan umpan balik serta penguatan bagi guru yang telah berhasil melaksanakan tugasnya dengan baik. Guru yang telah berhasil menyusun RPP daring dengan baik, maka diminta untuk menampilkan RPP yang telah disusunnya dan peserta lain diberi kesempatan untuk bertanya. Hal ini diharapkan juga dapat memberikan motivasi pada guru yang belum berhasil agar berimplikasi positif pada guru yang sedang mengikuti kegiatan.

c. Kesulitan guru pada umumnya adalah belum paham penggunaan aplikasi daring, sehingga mereka ragu untuk mencantumkan aplikasi tersebut dalam RPP.

d. Tindak lanjut yang dapat dilakukan adalah menjelaskan jenis-jenis aplikasi daring dalam pembelajaran. Memberikan contoh RPP dalam jaringan (daring).

\section{Siklus II}

1. Perencanaan Kegiatan

Adapun perencanaan yang peneliti lakukan pada siklus 2 ini adalah dengan berpedoman pada temuantemuan pada siklus 1 . Selanjutnya disusun rencana tindakan yang akan dilaksanakan pada siklus 2 ini, yaitu kembali melakukan kegiatan In House Training (IHT) bagi guru menyusun RPP daring. Hal ini dilakukan karena target keberhasiln belum tercapai. Peneliti menetapkan target kerberhasialn sebesar $85 \%$, sementara pada siklus 1 ini baru tercapai sebesar $70,42 \%$. Selain itu masih ada yang belum memahami tentang penempatan moda daring dalam RPP yang disusunnya. Maka selama In House Training, dan setiap ada kesempatan peneliti membuka diri untuk memberikan masukan kepada guru yang mengalami kendala. Bimbingan individual dianggap lebih baik, sehingga membuka peluang bagi guru untuk banyak bertanya dan berdiskusi dengan peneliti selaku supervisor. Selanjutnya baru menyiapkan dokumen yang dibutuhkan dalam pelaksanaan kegiatan nantinya, yaitu sebagai berikut:

a. Menentukan dan menyepakati jadwal kegiatan

b. Menjelaskan cara penggunaan moda daring dalam PJJ

c. Membuat instrumen penilaian RPP

d. Menyediakan format RPP

e. Membuat format catatan lapangan

f. Menyediakan contoh RPP daring 
2. Pelaksanaan Tindakan

Pertemuan pertama siklus 2 dilaksanakan pada hSenin, tanggal 10 Agustus 2020. Dalam pelaksanaan IHT pada siklus 2 ini penulis menjelaskan tentang jenis-jenis aplikasi daring dan cara penggunaannya dalam pembelajaran jarak jauh (PJJ). Hal ini dirasa perlu sebagai tindak lanjut dari refleksi pada siklus 1. Selanjutnya menjelaskan kembali tentang RPP daring. Kemudian guru kembali duduk berkelompok dengan mata pelajaran yang sama dan menyusun RPP daring. Penulis memberikan masukan bagi guru yang mengalami kendala dalam menyusun RPP daring.

Pertemuan kedua dilaksanakan pada Sabtu, tanggal 15 Agustus 2020. Peneliti meminta guru kembali duduk berkelompok untuk melakukan finishing terhadap RPP daring yang telah disusun, namun setiap guru tetap membuat RPP masing-masing. Tetapi dalam pengerjaannya mereka boleh berdiskusi dalam kelompok. Kemudian salah satu kelompok diminta untuk mepresentasikan hasil diskusinya dan ditanggapi oleh peserta yang lain. peneliti memberikan masukan. Setelah RPP kembali direvisi sesuai masukan, maka peneliti kembali meminta guru untuk mengumpulkan RPP yang dibuatnya. Peneliti dengan dibantu oleh observer mencek dan menilai RPP yang dibuat oleh guru, Kegiatan ini dilaksanakan siang harinya setelah jam pembelajaran biasa berakhir. Tujuannya adalah agar guru lebih fokus dan tidak menganggu PBM biasa. Kegiatan ini dimaksudkan agar pembelajaran jarak jauh lebih sesuai dengan perencanaan dan bermakna.

3. Observasi

Dalam pelaksanaan kegiatan ini peneliti mengamati kegiatan guru selama melaksanakan In House Training (IHT). Di samping itu juga meminta guru untuk mengumpulkan RPP daring yang dibuat untuk diberi penilain sesuai format yang telah ditentukan. Peneliti dibantu oleh observer selama melaksanakan pengamatan. Kompetensi guru dalam menyusun RPP daring pada siklus 2 ini telah menunjukkan kemajuan. Rata-rata dari pertemuan I (pertama) $84,16 \%$, pada pertemuan ke-2 (kedua) meningkat menjadi $91,67 \%$. Terjadi peningkatan sebesar Total rata-ratanya adalah $87,92 \%$. Jadi dapat disimpulkan bahwa terdapat peningkatan yang positif terhadap kompetensi guru dalam menyusun RPP daring secara signifikan pada siklus kedua ini. Jadi berdasarkan perolehan tersebut juga dapat disimpulkan bahwa target keberhasilan telah tercapai. Dimana peneliti menetapkan target keberhasilan adalah sebesar 85\%, sementara pada siklus 2 ini telah mencapai 87,92. Jadi telah melebihi target yang ditetapkan, maka penelitian ini tidak perlu dilanjutkan lagi. Sebagai perbadingan kompetensi guru menyusun RPP daring pada siklus 1 dengan siklus 2 dapat dilihat pada tabel 6 berikut:

Tabel $1<$ Perbadingan Kompetensi Guru dalam Menyusun RPP Daring antara Siklus 1 dengan Siklus 2>

\begin{tabular}{|c|c|c|c|c|c|}
\hline \multirow{2}{*}{ No } & \multirow{2}{*}{ Aspek yang diteliti } & \multicolumn{2}{|c|}{ Siklus } & \multicolumn{2}{|c|}{ Keterangannn } \\
\hline & & $1(\%)$ & $2(\%)$ & 1 & 2 \\
\hline 1 & Guru mencantumkan identitas dengan lengkap & 90 & 100 & $\mathrm{AB}$ & $\mathrm{AB}$ \\
\hline 2 & $\begin{array}{l}\text { Guru mencantum tujuan pembelajaran yang sesuai } \\
\text { dengan } K D \text { dan memuat } A B C D\end{array}$ & 57,5 & 82,5 & $\mathrm{C}$ & B \\
\hline 3. & $\begin{array}{l}\text { Guru mencantumkan kegiatan pendahuluan } \\
\text { (appersepsi, motivasi, menyampaikan tujuan, } \\
\text { menyampaikan kegiatan pembelajaran) }\end{array}$ & 70 & 90 & $\mathrm{C}$ & $\mathrm{AB}$ \\
\hline 4. & $\begin{array}{l}\text { Guru mencantumkan kegiatan Inti (memuat sintak } \\
\text { model, langkah penggunaan aplikasi yang sesuai, } \\
\text { penggunaan model pembelajaran) }\end{array}$ & 60 & 82,5 & $\mathrm{C}$ & B \\
\hline 5. & $\begin{array}{l}\text { Guru mencantumkan kegiatan penutup } \\
\text { (menyimpulkan, refleksi, penilaian proses, tindak } \\
\text { lanjut) }\end{array}$ & 77,5 & 87,5 & B & $\mathrm{AB}$ \\
\hline 6. & $\begin{array}{l}\text { Guru mencantumkan asesmen (sikap, pengetahuan, } \\
\text { keterampilan) dengan lengkap }\end{array}$ & 67,5 & 85 & $\mathrm{C}$ & B \\
\hline \multicolumn{2}{|c|}{ Rata-rata } & 70,42 & 87,92 & B & $\mathbf{A B}$ \\
\hline
\end{tabular}




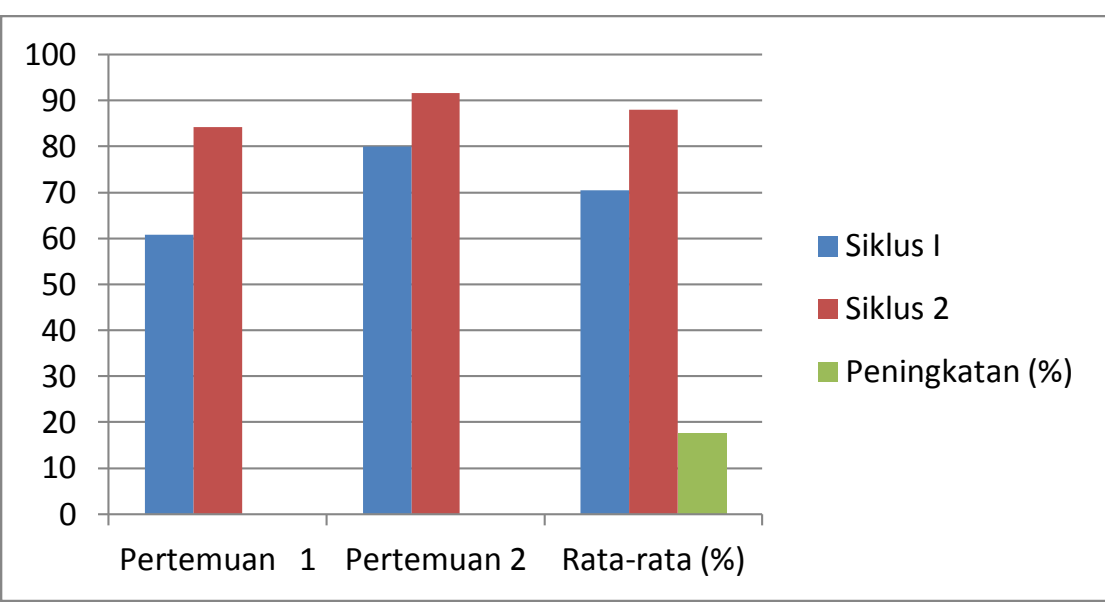

Gambar 1 < Perbandingan Kompetensi Guru dalam Menyusun RPP Daring antara Siklus 1 dengan Siklus 2>

Kompetensi guru yang terlihat pada tabel 6 dan grafik 2 di atas dapat diuraikan sebagai berikut:

a. Guru mencantumkan identitas dengan lengkap mengalami peningkatan dari $90 \%$ menjadi $100 \%$, jadi peningkatannya sebesar $0 \%$, dan telah maksimal.

b. Guru mencantum tujuan pembelajaran yang sesuai dengan $\mathrm{KD}$ dan memuat $\mathrm{ABCD}$, mengalami peningkatan dari siklus 1 sebesar 57,5\% menjadi 82,5\% pada siklus 2, jadi peningkatannya sebesar $25 \%$.

c. Guru mencantumkan kegiatan pendahuluan (appersepsi, motivasi, menyampaikan tujuan, menyampaikan kegiatan pembelajaran), pada siklus 1 sebesar $70 \%$ menjadi $90 \%$ pada siklus 2 . Jadi peningkatannya sebesar $20 \%$

d. Guru mencantumkan kegiatan Inti (memuat sintak model, langkah penggunaan aplikasi yang sesuai, penggunaan model pembelajaran), pada pertemuan pertama sebesar $60 \%$ menjadi $82,5 \%$ pada siklus 2 . Jadi meningkat sebesar $22,5 \%$

e. Guru mencantumkan kegiatan penutup (menyimpulkan, refleksi, penilaian proses, tindak lanjut), pada siklus 1 sebesar 77,5\%, menjadi 87,5\% pada siklus 2 . Jadi meningkat sebesar $10 \%$.

f. Guru mencantumkan asesmen (sikap, pengetahuan, keterampilan) dengan lengkap, pada pertemuan pertama sebesar $67,5 \%$, menjadi $85 \%$ pada siklus 2 . Jadi meningkat sebesar $17,5 \%$.

Tabel $2<$ Rentangan Penilaian $>$

\begin{tabular}{lll}
\hline & Nilai Kuantitatif & Keterangan \\
\hline $86-100$ & Amat baik & \\
$71-85$ & Baik & \\
$56-70$ & Cukup & \\
$<56$ & Kurang & \\
\hline
\end{tabular}

Tabel 3 <Peningkatan Kompetensi Guru Merancang RPP dari Siklus I ke Siklus 2>

\begin{tabular}{lcccc}
\hline Siklus & & Pertemuan 1 & Pertemuan 2 & Rata-rata (\%) \\
\hline Siklus I & 60,83 & & 80 & 70,42 \\
Siklus 2 & 84,16 & 91,67 & 87,92 \\
& & Peningkatan (\%) & & $\mathbf{1 7 , 5}$ \\
\hline
\end{tabular}

Pada siklus 1 kompetensi guru menyusun RPP Daring sebesar 70,42\%, pada siklus 2 meningkat menjadi $87,92 \%$. Terjadi peningkatan sebesar $17,5 \%$.

\section{Refleksi}

Berdasarkan hasil analisis yang dilakukan pada siklus 2 ini, dengan menggunakan metode In House Training (IHT) kompetensi guru dalam menyusun RPP Daring mengalami peningkatan yang sangat berarti.

Kompetensi guru dalam menyusun RPP Daring pada siklus I dengan 2 (dua) kali pertemuan dengan rentangan nilai rata-rata: pertemuan 1 sebesar 60,83\%, pada pertemuan 2 menjadi $80 \%$ dengan rata-ratanya sebesar 70,42\%.Pada siklus 2 dengan rentangan nilai pertemuan 1 sebesar $84,16 \%$, pada pertemuan 2 menjadi $91,67 \%$ dengan rata-rata sebesar 87,92\%. Peningkatan kompetensi guru dalam menyusun RPP Daring dari siklus 1 sebesar $70,42 \%$ menjadi $87,92 \%$ pada siklus 2 memberikan keterangan bahwa terjadi peningkatan 
sebesar 17,5\%. Jadi hipotesis tindakan terbukti bahwa In House Training (IHT) dapat meningkatkan kompetensi guru dalam menyusun RPP daring di UPTD SMPN 1 Kecamatan Luak. Peningkatan kompetensi guru ini karena tindakan yang dilakukan dapat memotivasi guru untuk menyusun RPP dalam jaringan (daring).

\section{Simpulan}

In House Training (IHT) adalah bentuk kegiatan pelatihan yang dilaksanakan secara interen, dimana tempat, materi pelatihan ditentukan sesuai dengan yang diminta dan dibutuhkan oleh peserta.Dalam pelaksanaan kegiatan In House Training (IHT) peneliti fokus pada kegiatan membimbing mereka dalam menyusun RPP daring Tujuannya adalah agar pelaksanaan pembelajaran yang dilakukan oleh guru sesuai dengan perencanaan. Fungsi RPP adalah dapat mendorong guru lebih siap melakukan kegiatan pembelajaran dengan perencanaan yang matang. Oleh karena itu, setiap akan melakukan pembelajaran guru wajib memiliki persiapan. Dengan menggunakan metode In house training dapat meningkatkan kompetensi guru dalam menyusun RPP daring yang dapat digunakan untuk pembelajaran jarak jauh (PJJ). Selanjutnya Pelaksanan PJJ menjadi lebih terarah dan bermakna serta terjalinnya hubungan kolegial antara kepala sekolah dengan guru dalam memecahkan masalah pembelajaran serta tugas-tugas profesinya.

\section{Referensi}

Anugrah, M. (2019). Penelitian Tindakan Kelas:(Langkah-Langkah Praktis Pelaksanaan Penelitian Tindakan Kelas): Penerbit LeutikaPrio.

Atsani, K. L. G. M. Z. (2020). Transformasi media pembelajaran pada masa Pandemi COVID-19. Al-Hikmah: Jurnal Studi Islam, 1(1), 82-93.

Darmadi, H. (2016). Tugas, peran, kompetensi, dan tanggung jawab menjadi guru profesional. Edukasi: Jurnal Pendidikan, 13(2), 161-174.

Erdianti, E. (2014). Strategi Kepala Sekolah sebagai Supervisor dalam Mengembangkan Kompetensi Profesional Guru. Al-TA'DIB: Jurnal Kajian Ilmu Kependidikan, 7(1), 37-53.

Jamaluddin, J. (2020). Peningkatan Kemampuan Guru Penyusunan RPP melalui Kegiatan In House Training (IHT). Jurnal Kinerja Kependidikan (JKK), 2(3), 510-523.

Jayadipura, Y. (2018). In House Training untuk Meningkatkan Kemampuan Guru dalam Menyusun RPP. Jurnal Idaarah, 2(2), 260-268.

Komariah, A. (2009). Melaksanakan Supervisi Akademis Melalui Penelitian Tindakan Sekolah (School Action Research). Jurnal Administrasi Pendidikan, 10(2).

Mahardhani, A. J. (2016). Kepemimpinan ideal kepala sekolah. Jurnal Dimensi Pendidikan Dan Pembelajaran, $3(2), 1-4$.

Majid, A. (2008). Perencanaan pembelajaran mengembangkan standar kompetensi guru. Bandung:Remaja Rosdakarya.

Mansyur, A. R. (2020). Dampak covid-19 terhadap dinamika pembelajaran di indonesia. Education and learning journal, 1(2), 113-123.

Muhardiansyah, A. (2019). Implementasi Usulan Penilaian Angka Kredit Berbasis Online (Sisdupak) Bagi Guru Dalam Upaya Peningkatan Manajemen Pelayanan Pendidikan (Studi Pada Dinas Pendidikan Kabupaten Malang). Universitas Brawijaya.

Nuridin, N., Maerani, I. A., Soleh, M. M. A., \& Anwar, K. (2019). Meningkatkan kompetensi kepala sekolah swasta di Kota Semarang berdasarkan Permendikbud Nomor 6 Tahun 2018. Indonesian Journal of Community Services, 1(2), 165-174.

Pendidikan, K., \& Indonesia, K. R. (2016). Permendikbud Nomor 22 Tahun 2016 Tentang Standar Proses Pendidikan Dan Menengah. Jakarta: Kemendikbud.

Pohan, N. A., \& Siregar, Y. E. Y. (2018). Peran supervisi kepala sekolah terhadap pelaksanaan tugas pokok guru: penelitian tindakan sekolah. Jurnal Pendidikan Dasar, 9(2), 132-139.

Putrianingsih, S., Muchasan, A., \& Syarif, M. (2021). Peran Perencanaan Pembelajaran Terhadap Kualitas Pengajaran. INOVATIF: Jurnal Penelitian Pendidikan, Agama dan Kebudayaan, 7(1), 138-163.

Sanjaya, W. (2015). Perencanaan dan desain sistem pembelajaran: Kencana.

Sudarwan, D. (2010). Motivasi Kepemimpinan dan Efektivitas Kelompok, Jakarta,. Rineka Cipta.

Widiyanto, I. P., \& Wahyuni, E. T. (2020). Implementasi Perencanaan Pembelajaran. Satya Sastraharing: Jurnal Manajemen, 4(2), 16-35. 
Zaedi, M., \& Rizkia, R. D. (2019). Analisis Model Pembelajaran Berkarakter dan Relevansinya Terhadap Pendidikan Islam (Studi Analisis Manajemen Pendidikan Karakter Perspektif E. Mulyasa). Risâlah, Jurnal Pendidikan dan Studi Islam, 5(2, Sept), 20-39. 